\title{
The knowledge system of Sicilian fortified dwelling-places: materials and building techniques related to Villa-Castle Maeggio in Siracusa countryside
}

\author{
F. Cantone, P. Carnazzo \& A. Giuffrida \\ Department of "Analisi, Rappresentazione e Progetto nelle Aree del \\ Mediterraneo" (ARP), Faculty of Architecture of Syracuse, \\ University of Catania, Italy
}

\begin{abstract}
The recovery process of the building starts from a basic phase of knowledge whose roots are to be searched in the materials and of the constructive technologies employed, and it takes into account the history of the building and how it changed over the years.

It is therefore necessary to examine the technological aspects by comparing both the materials and the constructive principles with those of areas having similar features, such as the fortified buildings in the south-east of Sicily. The case-study is a fortified villa designed in 1781 by Luciano Alì, an architect and builder who worked in Syracuse at the end of the 16th century.

This building, consisting of a central part and four quadrangular towers at the corners, has a strong decorative impact. This study aims to identify the materials and the constructive characteristics of the building, pointing out its peculiarities and assembling an informative system based on the original documents describing the technological choices. The investigation connected to the recovery consists in the systematisation of historical, documentary and technological data and the creation of a guideline.
\end{abstract}

Keywords: degradation, natural stone, recovery, diagnostic process, technological analysis. 


\section{Introduction}

For more than forty years the recovery process of a building has been subject to a lengthy debate, from which various study approaches have arisen [1]. The subject has been examined with much interest and consistency at a theoretical level. Unfortunately though, the practical testing, which could verify the correctness of the supported theory has been rare and discontinuous. Today, after many years of debates, conventions and the contribution of dozens of experts and at the expense of the building's recovery, a conceptual uncertainty still remains due to improper definitions and liberties that avoid following models and regulations.

Nevertheless, this extensive period has drawn knowledge in operating areas of the process of recovery, distinguishing methodologies that seize hidden specifics and abilities from the pre-existence, bringing from the daily practise the essential and the authenticity.

Therefore the recovery process requires both a conceptual and an operating effort to maintain the building's original authenticity and to prevent its demolition; the architect's ability together with the experts involved in the recovery operation play a great part in renewing the existing work while appreciating its value because 'the stone profoundly expresses what it contains, the walls remain implacable, and the work - in compliance with the truth strongly declares its strict destination [2].

\section{The knowledge system}

The building knowledge is an indispensable requirement for the technological operation finalized to recovery. In this perspective, it is fundamental to find and to organize information necessary to the building analysis.

Diagnostic process comprises two basic phases; one regards the analysis process organization, the other the acquired information selection. The formulation of such proceedings can influence the success of recovery operation and must be chosen according to circumstances. The basic element of recovery logic is just in the building oneness; in fact, through aimed and experienced researches according to the building characteristics, it is possible to reach data interpretations that lead to a series of information, that are followed by the project moment. Operation strategies are therefore individuated on the basis of the interpretation and the selection of this information. In any case, it is a matter of multidisciplinary analyses and contributions that are characteristic of diagnostic process.

It must be specified that diagnostics can and must be applied to various levels, according both to the dimensions and the characteristics of the building, and to the goal that has been set.

Knowing and analyzing a building mean to know its history, the events that have taken place there, the functions that it has gained, the changes that have been introduced and, not last, the materials by which it has been built and modified during the years. In this way diagnostic process becomes a moment of 
wide-ranging research, in order to reconstruct the building evolution and to characterize architectonic, technological, performances and maintenance outlook that is essential for the writing of the recovery plan. In fact diagnostic searches are of great help to the definition of the constructive, material and structural conditions of the building and give essential information about the operation choices.

In the study case it has been necessary to examine closely some fundamental aspects of the diagnostic process: first of all it has been indispensable to know the history and the transformations that the building has endured in the time, also being aware of main historical events that have characterized the South eastern zone of Sicily. In this first phase, information, coming from the private archives of Bonanno family, has been recovered that has cleared aspects regarding the planning, the construction and the management of the building.

Just some considerations of distributive kind, that have constituted the second phase of research, have been the cue for an analysis that had as reference not the technical elements, such as masonries, covers, openings, floors etc, but the technological units made up of the rooms, that assumed valence as such. It means that blocks have been formed on which a decomposition has been made, in which primary elements were the function of the rooms and its position inside the distributive diagram, put in relation with the morphology, the material consistency and the accomplishment techniques of the rooms.

The third phase has involved the material consistency of the blocks, having the technical elements analysis like starting point. In particular the materials used for the building and the constructive techniques have been examined closely. Two standard cards (tables A-B) are here introduced showing the functional decomposition and the analysis of the technical elements presents in the above mentioned rooms.

The last phase of the investigation has been the analysis of the state of the surfaces and their degradation.

\subsection{The historical analysis}

The villa arises on a feudalist estate which takes the name from the Arabic word Maeggio meaning 'flatland' [3]. The origin of this place goes back to 1408, when the estate was property of the family De Baldo [4]; in 1782, it was passed to Giuseppe Bonanno Landolina, Prince of Linguaglossa [5] who, being satisfied by the work of the architect Luciano Alì for the creation of Palazzo Bonanno in Siracusa, commissioned him the building of the sumptuous actual structure.

The architect/builder worked on the planning and the direction of the works until 1784. From 1851 to 1853 , under the direction of the mason Sebastiano Rodante, additional residences and a new millstone were built using the most advanced techniques of the period [6].

Some scripts reveal [7] that the building of towers often indicated the owner's wealth or the beginning of family's possession. Originally built as a defensive measure or for military purposes, they were converted later into rural buildings for agricultural activities and transformed into farmhouses and warehouses. In more recent times the side towers have been used as olives and almonds 
Table 1: $\quad$ Villa Castello Maeggio - building characteristic.

VILLA CASTELLO
MAEGGIO

Siracusa - Sicily - Italy

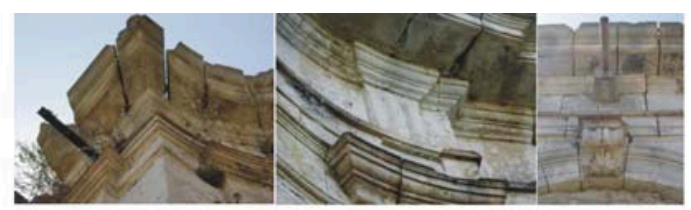

THE MANOR HOUSE

\section{Construction age}

XVIII Century

\section{Former use}

Residential

\section{Changes of use}

\section{Neglect}

\section{Owner}

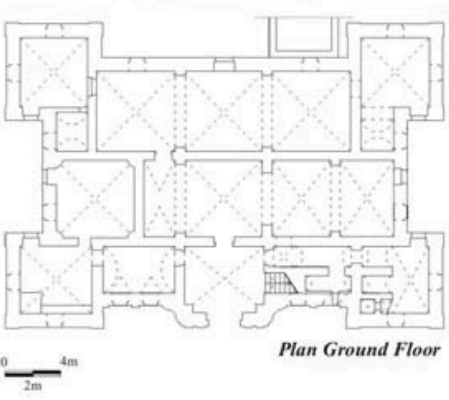

Private

\section{Dimensions}

Indoor area : $391 \mathrm{~m} 2$

Outdoor area : $603 \mathrm{~m} 2$

Volume : $7053 \mathrm{~m} 3$

\section{Building characteristics}

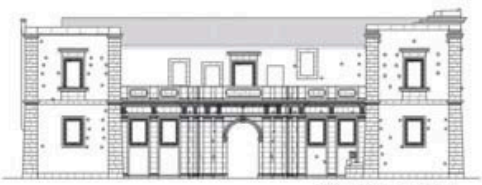

It is built in a far zone from the inhabited centre, it has an austere aspect with a central body and four side towers, that highlights a probable defensive function. On the back of the villa and in its neighbourhood there are rural habitations, big cattle shed and several storehouses.

The building was planned in 1781 by architect Luciano Ali.

Decorations on string- courses, capitals, pilasters strips, ornaments, metopes and triglyphs, which are in contrast strongly with austerity's system are noticed.

The planimetric system is formed by a principal rectangular body ( $26 \times 18$ metres), and at its corners there are inserted four square towers (the side is 7 metres). At the ground floor there are six big rooms ( $18 \times 5,5$ metres), divided in spans, covered with cross vault ending with decorated corbels; the other rooms are covered with barrel vault. The internal staircase, that lead to the second level, is decentred respect the construction, and it is the only element that break the rigid planimetric symmetry.

The villa, inhabited till some decade ago, actually is neglected and it is in state of decline.

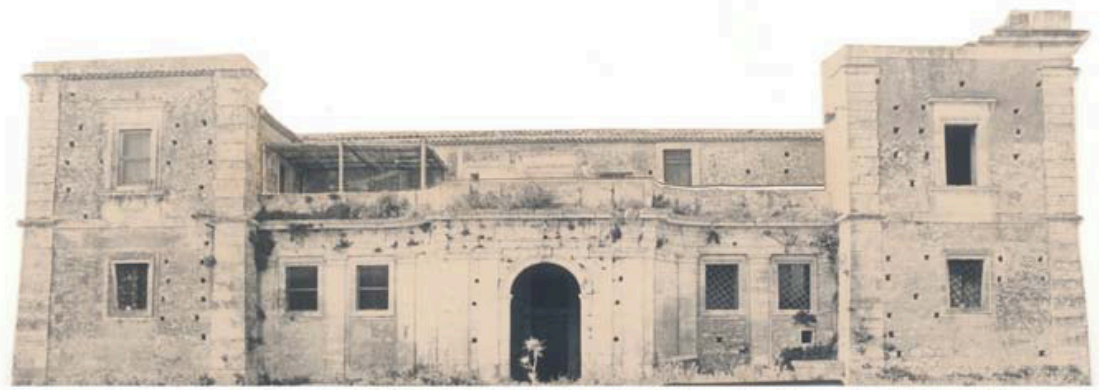


warehouses. Located underneath the construction was a cistern and a millstone on the rear side, however after its demolition in the 1960s, no traces are left of the latter.

\subsection{The analysis of the materials, the constructive techniques and the technical elements}

The survey and the technical details of the structure allow a clear understanding of the building's stability and its whole framework. Therefore the technical analysis provides information concerning the variations and detrimental effects that the building has endured over time.

The study herewith has examined the several technical elements and has detected specifics and similarities according to their position and aggregation in the building. The results shown in this refer to block 1, identified as linking space for the two towers. See elevation A-B of the building (table 3 and 4).

The technical survey focuses on underlining the building's characteristics through a systematic division of the structure and the analysis of its attitudes.

The analysis of recorded studies has revealed that the material used in the foundations of the villa was a hard limestone quarried in the same Maeggio area together with lime mortar and river sand. The documentation shows that the foundation has a depth of "five palms" (traditional unit of measure) and rests directly on a live rock. Further, it shows that previous to laying the foundations, preventative levelling works has been taken. The external brick work which creates the supporting structure of the building, presents different level of thickness: the inner walls have consistent dimensions while the external ones narrow down on the floor above, having respectively measures of four "palms" (approximately mm. 1000) and three "palms" (approximately mm. 750).

Table 2: $\quad$ Characteristic data of the Syracusan stone used in the building.

\begin{tabular}{|c|c|c|c|}
\hline Name & Family & Colour & Technical property \\
\hline \multirow{8}{*}{$\begin{array}{l}\text { The stone } \\
\text { of Syracuse }\end{array}$} & \multirow{8}{*}{$\begin{array}{l}\text { Compact } \\
\text { limestone }\end{array}$} & \multirow{8}{*}{$\begin{array}{l}\text { White and } \\
\text { grey }\end{array}$} & Calcareous composition: $95.1 \%$ \\
\hline & & & Density: $2.600-2.800 \mathrm{~kg} / \mathrm{mc}$ \\
\hline & & & Porosity: $34-40 \%$ \\
\hline & & & $\begin{array}{l}\text { Soaking by capillary: } 15 \% \\
\text { Soaking by immersion: } 17 \%\end{array}$ \\
\hline & & & $\begin{array}{l}\text { Thermic conductivity: } 0.9-1.7 \\
\text { Kcal } / \mathrm{mh}^{\circ} \mathrm{C} .\end{array}$ \\
\hline & & & $\begin{array}{l}\text { Compressive strength: from } 85 \text { to } \\
\qquad 184 \mathrm{Kg} / \mathrm{cmq}\end{array}$ \\
\hline & & & $\begin{array}{l}\text { Flexural strength : from } 26 \text { to } 71 \\
\mathrm{Kg} / \mathrm{cmq}\end{array}$ \\
\hline & & & Specific gravity: $2740 \mathrm{Kg} / \mathrm{mc}$ \\
\hline
\end{tabular}


Table 3: $\quad$ Analysis of technological elements - Block 1 - Table A.

\section{VILLA CASTELLO MAEGGIO - SIRACUSA} TECHNOLOGICAL ANALYSIS - Table A
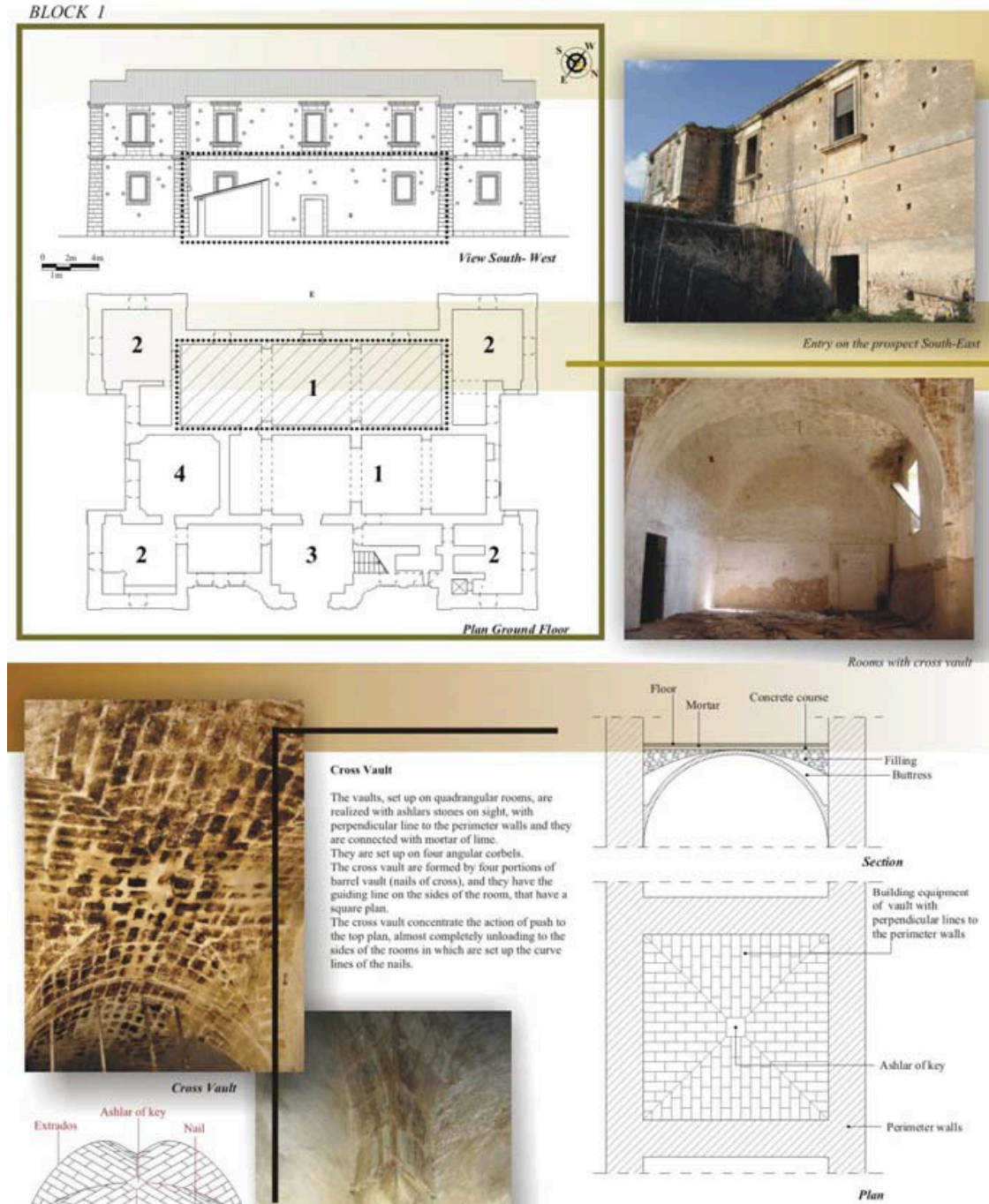

The constructive technique base itself on the realization of the vault from the impost, going on to the key with the key ashlas positioning.

Spent the necessary time for the hold of the materials and for the structural arrangement, the disarmament of the centre is made, to ensure that the vault enters in load.

The use of cross vault, ending with deconted corbels, recurs in the big halls to the ground floor. 
Table 4: $\quad$ Analysis of technological elements - Block 1-Table B.

\section{VILLA CASTELLO MAEGGIO - SIRACUSA}

TECHNOLOGICAL ANALYSIS - Table B

BLOCK I

\section{Masonries in elevation}

Masonry realized in rustic head of stones of suitable consistency, placed in lines levelled up in horizontal, with tip ashlars laid upon the vertical one.

There are giant elements, distributed on all the face and these are alternate to littler elements, with smaller carrying function.

In the building face the elements are levelled up in situated regular with stone chips.

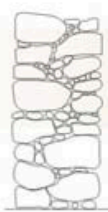

Section 2-2*

LEGEND

T= elements of tip $S=$ elements of strip L- levelling up
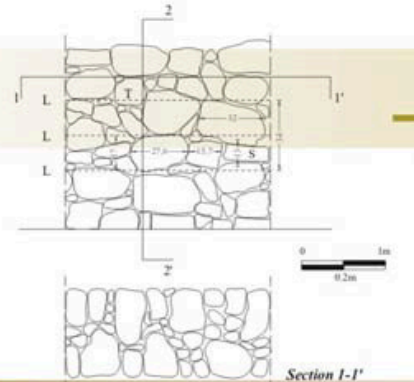

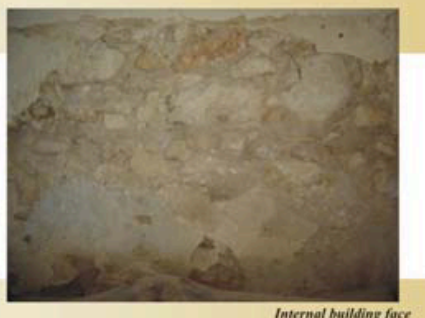

Internal building face Face and section

Masonry of calcareous rough-hewn stone, installed with mortar made of lime and inert calcareous, realized with levellings up, and suitable consistency stones.

The building device is composed of irregular ashlars and of medium- little elements which have filling function and they give a better arrangement of the elements placed in strip and tip position.

\section{Openings}

All the openings are surrounded by frames of cut stone, composed of a threshold, two shoulder harms and an architrave.

The external architrave is always stony; the ashlars which compose it are in over-squaring respect to the plaster thread and they penetrate the wall for about $20 \mathrm{~cm}$ (a third of the average wall thickness). In the remaining two third, placed the internal

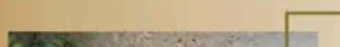

\section{architrave. \\ architrave.}

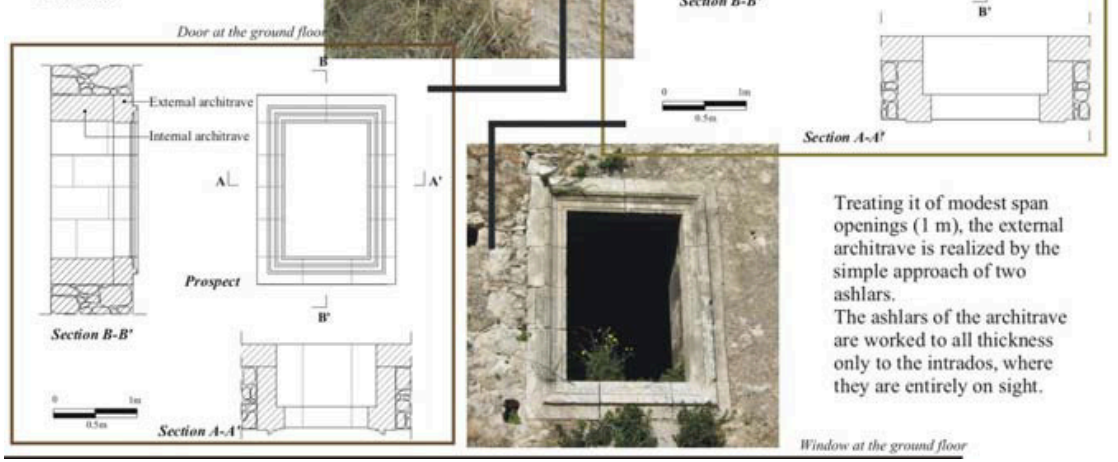

The walls' structure is of compact limestone blocks (table 2), mostly large sized and tied with lime mortar and river sand, covered with plaster both in the 
inner and external side. Internally, the mortar dosage has a ratio proportion equal to $1: 1$ of lime and inert material, and the lime paste softened together with a best quality stone and prepared four days before its usage.

The masonry work shows the use of large stone elements, placed on band and tip: band elements vary from a minimum of mm. 260 to a maximum of $\mathrm{mm}$. 320 , with $170 \mathrm{~mm}$ in the height, while tip elements range from $\mathrm{mm} .150$ to 170 in the side, with heights of approximately mm. 130-140.

The inert material employed in the mortar composition is the river sand, known as "Arena di Lavinaro": it is detritus sediment of medium granulometry, generated from the cliff disintegration over a chemistry or mechanic action and deposited on the river beds.

As to the building openings, they are spaced in a symmetrical way and with equal dimensions, with the exception of those that overlook the terrace, probably made at a later stage. Both doors and windows are framed with jambs and architraves in white strong stone; the main entrance is surmounted by an round arch, of which joints converge towards the centre of the lower surface line; the keystone block is decorated and the pulvins on the arch do not rest directly upon the pier but upon the capitals. The portal is not aligned to the elevation but is connected to the wall through concave surfaces, which creates shading features.

The Maeggio villa's ceilings are formed by one single roof layer with different main and secondary materials: almost evenly, the main warp is formed of wood beams, tilted according to the roof slope (approximately 30\%) and embedded to the masonry work, while the secondary warp is made of purlins, parallel to the smaller side of the space on which tiles rest directly, or by canes tied together, on which tiles are adjusted.

False ceilings were built in the 60 s using thick wood partitions positioned at a 90 degree angle to the course of the main beams, in their turn embedded to the wall or to the course of the thin wooden beams that form also its "cordolo" and covers the perimeter of the room. In this instance, the cover is only one layer with main structure of wooden beams, on which canes rest tied together with roofing-tiles.

On the ground floor the halls are separated in three spans, m. 18 long and $\mathrm{m}$. 5.5 wide and covered with cross vaults ending with decorated corbels, while smaller rooms have barrel vaults covers. The two levels are connected by an inner staircase, away from the centre based on the symmetrical system of the building. In the back of the villa hosts the rooms of the workers, ample stables and a various sheds.

\subsection{The analysis of the conservation state}

The study of façades [8] has lead to the location of numerous degradations both on stone elements and on plaster. As previously said, the stone, by which frames, corners, and decorated elements are realized, is a compact and white limestone that has stood up well to the attacks of the atmospheric agents. Degradations of biological origin are present on it, caused by the sliding of meteoric waters on the façades, because of shortage and breakdowns in cover, 
that fully concern all the façades. The following degradations have been individuated and localized:

On the stone:

- Crusts of biological origin on mot enough sunny façades;

- Chromatic alteration on the crams of openings jambs and in the basement corners;

- Lichens of dark colour on ashlar corners, in median zone;

- Diffused biological patina that has not notched the substrate.

On the plaster:

- Biological patina with damage of plaster over which it has been installed;

- Lack of material in zones subject to the sliding of meteoric waters;

- Pulverization of plaster in basement zones close to the ground;

- Flos tectorii, characteristic biological degradation of the plaster, caused by a fungus that produces selective shapes of disintegration;

- Presence of vegetation on the top of the towers.

Moreover it is underlined that there are not crackings and fractures, that the structure is integral as to the structural profile, with the exception of some disconnections of the decorated apparatuses on which lack of cohesion and disintegrations of the mortar in the joints have been found.

\section{Conclusions}

The knowledge system [9], in the recovery process, places the bases for an aware and controlled plan that considers an always increasing number of architectonic, historical, environmental and economic factors, in which a right amount of information, of methods and systems of information selection, guiding the decisional process, is demanded.

Apart from the fact that the object of the recovery operation is a building or urban environment, the elements that must be estimated lead to a set of articulate and complex relations that the planner has to able to know in order to produce project scenes, based on the specificities of the object and not on the schematic, repetitive and sterile routine analyses.

In this sense the operation solutions begin from the adequacy of the knowledge system, from an effective selection of the information, both in qualitative and in quantitative terms, that allows to diminish the errors and to verify the feasibility of the proposed choices.

Therefore, the proposed method of analysis is a possible choice and a selection of the information, based on the distributive and functional characteristics of the building, in relation with the fundamental concept that the recovery is realized through a first phase of diagnosis followed by an aimed therapy. 


\section{References}

[1] Bruno, G., Il recupero della città esistente. Saggi 1968 - 1992, Etas Libri, Milano, 1993.

[2] Valéry, P., Eupalinos ou l'Architecte, Paris, 1921 (Italian translation, Contu, R., Eupalino o l'Architetto, Barabba di Lanciano Editore, 1932).

[3] Vittorio, A., Toponomastica del territorio siracusano, Vol. I, ANISN, Siracusa, 1986.

[4] San Martino De Spucches, F., La storia dei feudi e dei titoli nobiliari di Sicilia dalla loro origine ai nostri giorni (1923), Boccone del Povero, voll. IV- VIII- IX- X, Palermo, 1941.

[5] Luca Barberi,G., Capibreve dei feudi della Val di Noto, Michele Amenta, Palermo, 1879.

[6] The private Archives of the Bonanno family, envelope $n^{\circ} 1$ and 12.

[7] Bovo, A., Le torri di Siracusa e la difesa della città, Editore Maura Morrone, Siracusa, 1999.

[8] Cantone F., Viola S., Governare le trasformazioni. Un progetto per le corti di Ortigia, Guida Editore, Napoli, 2002.

[9] Caterina G. (a cura di), Criteri di intervento per il recupero del costruito, Istituto Italiano di Studi Filosofici, Università degli Studi di Catania, Facoltà di Architettura di Siracusa Liguori Editore, Napoli, 2003. 